\title{
A Lexico-syntactic Comparative Analysis of Ondo and Ikale Dialects of the Yoruba Language
}

\author{
Omoniyi Moses Ayeomoni \\ Department of English, Obafemi Awolowo University, Ile-Ife, Nigeria \\ Email: ayestyle@yahoo.com
}

\begin{abstract}
The study was a comparative study of Ondo and Ikale dialects of the Yoruba language with a view to finding out the areas of convergences and divergences between the two dialects. The study was based on 50 sentences selected from each of the dialects, but only 25 of the sentences were presented and used in this study. They were anaylsed from the perspective of Halliday Systemic Function Grammar (SFG) in order to identify the prominent lexemes and syntactic structures in the two dialects. Simple statistics based on percentages was used to calculate the number of lexemes and structures that are similar and different. It was discovered that the two dialects have basically the same lexemes at both subject and predicator levels. This shows that the speakers of the two dialects often make use of the same nominal and verbal items in their speeches. Besides, the two dialects share basically the same syntactic components - Subjects, Predicator, Complement and Adjunct as found in all the sentences examined. The dialects are however, found to be mainly different in the area of auxiliary verbs. Most of the words or lexemes in the dialects are also found in the standard Yoruba language, hence the mutual intelligibility of the two dialects to an average Yoruba language native speaker. It is thus envisaged that other dialects of Yoruba language that are geographically close may equally share similar linguistic features in the areas of lexemes and syntax.
\end{abstract}

Index Terms-Yoruba Language, Ondo dialect, Ikale dialect and comparison

\section{INTRODUCTION}

No human language is fixed, uniform, or unvarying; all languages show internal variation. The actual usage varies from group to group and from speaker to speaker in terms of pronunciation, choice of words, meanings or semantics, and syntactic constructions. So, this study looks at both variations and similarities in the dialects of Nigerian languages with respect to Yoruba language, which is mainly spoken in the South West of Nigeria and some countries in the West African sub-region.

Languages all over the world are noted for variation pervasiveness. English for example, has so many variations such as British English, American English, Australian English, South-African English, Nigerian English and so on etc. For instance, American English ( $A M E$ ) is noticeably different from that of the British, and the speeches of these two groups in turn are distinct from Australian English. When speakers of a particular language speak different versions of the language, they are said to be speaking different dialects of the language, which differs from register. The term 'register' first came into general currency in 1960s, and Halliday et al; (1964) described register "as a variety according to use in the sense that each speaker has a range of varieties which he chooses from, at different times" (p. 77). On the other hand, dialect is a variety according to user as the speaker uses only one variety and uses it all the time.

The common factor in this definition of register is the view that both situational and linguistic variables should be essential part of the process of register characterization. It is these situational variables that specify register as a variety according to use. Hence, in Sociolinguistics, Salami (2010) posits that "Ethnography of speaking and anthropological linguistics are concerned with the knowledge of language and the knowledge of its social and cultural use" (Salami 2010).

\section{A. What is Dialect of a Language?}

A dialect is a distinct form or a variety of a language; it is associated with a recognizable regional, social or ethnic group and different from other forms of the language by specific linguistic features such as pronunciation, vocabulary, grammar or any combination of these. In any event, it must be kept in mind that from the linguistic point of view, a dialect is a theoretical concept; it is a variation of language, and variation is so pervasive that each language is actually a continuum of languages and differs from speaker to speaker, and from group to group in such a way that an absolute lines can be drawn between different forms of or varieties of a language (See Labov, (1966), (1972); Milroy, (1987); Salami,(2006))

\section{B. Historical Survey of Dialect}

The rise of the discipline of sociolinguistics introduced the consideration of social and demographic factors into the description and analysis of languages and language varieties. This has made the study of dialects a significant area in the understanding of not only human behaviour, but also of the processes of language change. However, according to 
Salami (2010), "the study of the dialects of Yoruba (including the koine), so far, has followed largely the two frameworks of traditional dialectology and descriptive linguistics to the neglect of social dialectology and variation" (Salami 2010) (see, for example, Adetugbo, (1967), (1973); Oyelaran, (1976); Awobuluyi, (1992); Fabunmi, (1998), (2006), (2009); Ajongolo, (2005) and Aboderin (2006)).

The classical form of a dialect is the regional dialect, which is a distinct form of a language spoken in a certain geographical area. For instance, we have the Cockney-dialect, Yorkshire-dialect of English. Inhabitants of these regions have certain distinct linguistic features that differentiate them from speakers of other forms of English. Also, Tohomo O' odhan (formerly papago) and Akimel O' odhan (formely pima) are two native American languages spoken by members of some tribal groups living in the states of Arizona and Northern Mexico. The languages are close phonologically and grammatically with only minor linguistic differences in pronunciation and syntax (dialect variation). So, the phenomenon of dialect arose from the kind of language or the distinct form of a language spoken by members of a specific socio-economic class like the working class dialects in England or the ghetto languages in the United States.

Working class (England)

(i) He is fast in everything he does

(ii) You are out of the game

(iii) They are not caught

(iv) He is going to try get up

(v) She is the first one, that started us off

(Labov 1963).
Ghetto (United State)

(i) He fast in everything he does

(ii) You out the game

(iii) They not caught

(iv) He gon' try get up

(v) She the first one started us off.

\section{The Ethnic Dialects}

An Ethnic dialect can be described as the form of English sometimes referred to as 'Yiddish' English, historically associated with speakers of Eastern European Jewish ancestry. Language variation does not end with dialect, as we have differences among speakers, and can also be linked to a particular region of the country or to a particular social class or ethnic group even individuals. Each recognizable dialect of a language is still equally subject to considerable internal variation, no two speakers of a language, even, if they are speakers of the same dialect produce and use their language in exactly the same way. It is in this sense that we are able to recognize different individuals by their distinct speech and language patterns. Indeed, a person's language pattern is one of the most fundamental features of self-identity. And the form of a language spoken by a single individual is referred to as Idiolect, and every speaker of a language has a distinct idiolect. Once we realize that variation in language is pervasive, it becomes apparent that there is no such a thing as a single language used as at all times by all speakers. There is nothing like single English language, rather there are many English Languages (dialects and idiolects) depending on who is using the language and the context in which it is used, hence the terminology 'New Englishes'. For instance, the vocabulary differences between American and British English are often amusing. Indeed at a time, a pamphlet entitled, "Getting around the USA: Travel Tips for the British visitors", which contains a section labelled "How to say it" was printed and contains the following differences between British and American dialects of English:

\section{British Dialect}

Car park

Coach

Garage

Lift

Lorry

Petrol

Call box

Minerals

Vest

Lay by

\author{
American Dialect \\ Parking lot \\ Bus \\ Service Station \\ Elevator \\ Truck \\ Gasoline \\ Telephone Booth \\ Softdrinks \\ Undershirt \\ Rest area.
}

These examples are typical of the sort of dialectal variations found in the vocabulary of British and American Englishes. Finally, there are two other kinds of variation of English languages which I would also want to touch briefly. They are PIDGIN AND CREOLE which developed during and after the slave Era of the $17^{\text {th }}$ century. Now, under slavery, a large number of people were able neither to maintain their ancestral Languages nor shift to the colonial language. Instead, they created new languages (Pidgins and Creoles) that were partly based on the languages around them. These sentences illustrate typical forms of pidgins in Cameroon:

This small swine he been go for market

This small swine he been stay for house

This small swine he no been shop no nothing

And this small swine, he been go wee, wee sotei for house.

This version of 'This Little Piggy' recited by a speaker in Cameroon may seem highly unusual form from the view point of the convention of ordinary written English. Yet, sociolinguists who have spent their working career, studying such forms of speech, conclude that they are system in their own right, with their own linguistic norms. The technical term, for the language exemplified here is pidgin, and it is from Cameroon Pidgin English. There is also the Nigerian 
variety of Pidgin English which is widely spoken in the South-East and South-South part of Nigeria. In the South-West, where Yoruba race reside, it is equally but rarely spoken. Generally, the situation today is that Pidgin flourishes as a medium of inter-ethnic communication among less educated people in the southern part of Nigeria. The above Cameroon pidgin expressions could be rendered this way in Yoruba-Nigeria pidgin.

This small swine wey dey go market

This small swine wey dey stay for house

This small swine wey no dey shop anything

And this small swine, I dey go sotei for house.

\section{Nigerian Situation}

Nigeria is a multilingual society with various kinds of languages (Indigenous and non-indigenous). The exact number of indigenous languages in Nigeria is still very controversial. Jowitt (2005), posits that "its estimates range from 200 to over 400" (Jowitt, 2005). The problem of getting the accurate figure is a linguistic one, which has to do with differentiating language from dialect, and of deciding how to classify a particular speech-system that serves as communication medium within a social group. However, Salami (2010), argues that "dialectologists have been able to provide working definitions that have helped to explain the index for classification of the Nigeria languages and their dialects, which are variations by virtue of the fact that speakers live in different geographical locations, and belong to different social groups and networks, and are of different ages and genders" (Salami, 2010). In addition to these, English Language is the language of official transaction which is the bane of the modern Nigerian culture that is highly influenced by western political, educational and technological cultures. We also have the Nigerian Pidgin, which is much wide spread, but still not a lingua franca in the national sense. It is neither an elaborate code nor a restricted code. It is unlike the Tanzania Swahili, which is a language of broad social communication. It is also, totally different form the Standard English spoken in Britain and America. The three major Nigerian Languages are Yoruba language, Hausa language and Igbo language. These languages are different from one another in every respect.

\section{E. The Yoruba Language and Its Various Speakers}

The Yoruba language is one of the three major languages recognized officially in Nigeria. It is spoken in the SouthWest of Nigeria and in two other West African Countries, which are Republic of Benin and Togo. In Nigeria alone, the native speakers of the language are over 15 million, while another 5 million speak it in addition to their mother tongue. The language is spoken in the South West and South Central parts of Nigeria, comprising Oyo, Lagos, Ondo, Osun, Ekiti, Ogun, some part of Kwara states and a small portion of Edo and Kogi States. Like other native languages, it is a tonal language, having three surface tones - High, Mid and Low tone.

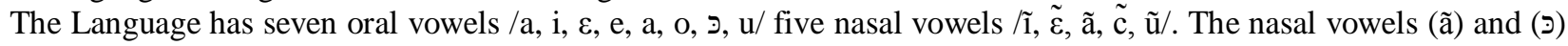
are found in different dialects. For instance, / $\ni /$ is found mainly in the dialect of Lagos, Egba, and Ijebu, while / ã / is mainly found in dialects of Ikalę, Ilaję, Ondo, ọwọ, e.t.c. while (כ) characterizes most of the south-west dialects that is, Lagos, Egba and Ijebu while (ã) characterizes most of the other dialects.

The Yoruba language has several dialects such as Oyo, Ijȩ̧̣, Ekiti , Owo, Akure, Ondo, Ife, Igbomina, Ilorin, Yagba, Ibunu, Egba Ilaje, Ikale, Egun, Akoko, Owe (Benin Rebublic), Sabee (Togo) and Popo (Togo). All these dialects vary slightly from one another, while some are totally different especially the Yoruba spoken outside Nigeria. Now, let us consider the following Yoruba words spoken by different speakers of Yoruba Languages to confirm their similarities and differences:

TABLE 1

\begin{tabular}{|l|l|l|l|l|l|l|}
\hline & Yoruba Oyo & Yoruba Ikale & Yoruba Ijesa & Yoruba Ondo & Yoruba Ekiti & Meanings in English \\
\hline I & wá & bọ bé & kàríorán & bọ bé & Ia & Come \\
\hline II & Isu & usu & Usu & Usu & usu \\
\hline III & ile & ule & Ule & uli & ule & Ham \\
\hline IV & omọ wa & ọmọ wa & ọmọria & ọm wa & omọ ra & Our child \\
\hline V & Isalẹ & ẹri & odo & Omi & odo & Down/River \\
\hline VI & Ijoko & otíta & Ujoko & akààbà & otita \\
\hline VII & ewure & Ikegbe & Ehevegbe & Ikegbe & ehure & Goat \\
\hline VIII & adiyẹ & ẹdiye & ẹdiyẹ & adie & ẹdiẹ & Fowl \\
\hline IX & ilẹkun & Ilẹkùn & àgandii & ilekun & aganrandi & Door \\
\hline
\end{tabular}

In all the cases above, the meanings are the same but in (v) the words (Isalẹ) spoken by the Ijèsa as Odo has a different meaning from down which means (River). Each word of the dialects above is very similar to Oyo dialect on which the standard Yoruba is derived. This shows that a reasonable number of the words in the dialects of Yoruba language are closely related or similar in structure and meanings to those in Oyo dialect. For instance, on the table above, the Oyo dialect of Yoruba uses the word- Isu for yam, while other dialects, render it as -Usu /uSu/. Also, the word 'fowl' in Oyo dialect is called Adiye, while in other dialects considered above, it is called Ediye except in Ondo dialect where it is rendered as Adię. Then another word that has a similar rendition in all the dialects is Goat, which is called ewúré in Oyo dialect, but has slightly different references in other dialects (see the above table). However, the 
label for it in Ekiti dialect is ehúrę, which is similar to that of Oyo dialect. Equally, the word 'house' in Oyo dialect is called Ilé, while references to it in other dialects are Ulé and Uli, which are similar to that of Oyo dialect.

So, the words in most of the dialects that are close in meanings, and similar in structure to those in Oyo dialect, where the standard Yoruba is derived. This thus accounts for mutual intelligibility of all the dialects of Yoruba language among the speakers of the language. However, the details of this are not the foci of this paper. The paper is on comparative study of two dialects of the Yoruba language, which are Ondo and Ikale dialects.

\section{Comparative Study OF ONdo AND IKale Dialects of Yoruba LANGUAGE}

This study is basically on the comparative study of Ondo and Ikale dialects of the Yoruba language. The study is informed by the relatedness of the dialects and the geographical proximity of the areas inhabited by the speakers of the two dialects to one another. Since the speakers of the dialects share geographical boundaries in the central and Southern senatorial districts of Ondo State of Nigeria; they also have a lot of cultural norms and activities in common. So, the study is out to find out the extent of the similarities and differences between the two dialects and the consequences of these on the traditions and cultures of the Ondo and Ikale people.

\section{A. Data for the Study}

The study is based on fifty sentences that were recorded from the native speakers of the two dialects. However, since it has been discovered that direct tape recorded interviews often jeopardize the chance of gaining direct access to naturalness of language use, that is, the observer's paradox; therefore, the use of unstructured spontaneous recorded conversations becomes inevitable. Even Milroy (1980), confirms this, when he claims that "recorded interviews render a speech unnatural and could mar the result of an investigation" (Milroy, 1980). As a result of these deficiencies of the recorded interview system, we then result to spontaneously surreptitious recording of the speeches of Ondo and Ikale native speakers. The respondents to these unstructured spontaneously speeches are later made to be aware of the recording exercise. However, the investigator jealously guides against allowing the knowledge of the recording to mar and impede the chance of getting the speeches in their natural form and use. The recordings were played back to the respondents, for them to raise objections to any part of the recording if necessary, and this is immediately erased in order to avert suspicions. The sentences are later transcribed and written out for comparative analysis. The analysis is based on the orthographic representation of the words and sentences using comparative approach. In order to carry out a detailed and thorough analysis, only twenty five of the sentences could be presented. And we strongly believe that these will reflect the general forms and patterns of the two dialects. The sentences are analyzed from the perspective of Halliday's Systemic Functional Linguistic (SFL) (2004). The Systemic Functional Linguistic (SFL) shows that language has a series of system, and each system is a set of options available to a speaker or writer in a given social environment. Grammar is a fractional part of form, which has four basic categories: Unit, $\underline{\text { Structure, }}$ Class and System. A unit is a kind of a stretch of language with a definite pattern. The relationship among them is such that each unit operates in the structure of the unit above it. The unit word, for instance, functions in the group, which is the unit above it, while the group operates in the clause, and the clause in the sentence. So, in this paper, the clause is the basic Unit of description, which is split into SPCA structure that is, the Subject, Predicator, Complement and Adjunct. Through this structure, it is possible to generate as many sentences as possible. It is part of the norm in Systemic Grammar to adopt statistical Procedures to analyse the observations of what people say and write in a particular social circumstance or situation, hence the adoption of this grammatical model for use in this paper. 
TABLE 2

\begin{tabular}{|c|c|c|c|}
\hline & Ondo Dialect & Ikale Dialect & English Translation \\
\hline 1 & We dà ti lọ in? & We ti lo?? & Haven't you gone? \\
\hline 2 & La ba un. & La ba & Go and meet him \\
\hline 3 & Iwé ne saa? & Iwé ni hánán? & Where is the book? \\
\hline 4 & Wá jẹun & Wá jeun & Come and eat \\
\hline 5 & Kí bi we lọ sí ? & Kí bo we lọ hí? & Where did you go? \\
\hline 6 & ọkọ nẹ ti sa ju & ọkọ rè ti háré jù & The motor is over speeding \\
\hline 7 & Móghó nì kò mí & Móghó ẹn mi & Give me the money \\
\hline 8 & We ka sákò in & Wé ka hà un & You had better run away from him \\
\hline 9 & Me la kàwé & Me la kàwé & I'm going to read \\
\hline 10 & Ma ií ẹ nọ́la o & Ma ri ẹ nọla o & I will see you tomorrow \\
\hline 11 & Odòwuọ́ọ̣ & Ódòwú ọ & Good night \\
\hline 12 & Káárọo o & Káa rọ ò & Good morning \\
\hline 13 & Kín tì ií kẹ? & Kí ngho ti gha kẹ? & How are things? \\
\hline 14 & La jókò si bẹ in & Lajókò hi bèyìn & Go and sit down there \\
\hline 15 & Kií gùwè bọ?? & Kí gbo w obọ? & When did you come? \\
\hline 16 & È lú wee tộ? & Ké lú we taa? & How much are you selling it? \\
\hline 17 & La à sùn & La a hùn & Go and sleep \\
\hline 18 & Èmí eé & Emì rée & Here I am \\
\hline 19 & Dó ji mi nówuọ & Jẹ ji mi nó wúò & Wake me up in the morning \\
\hline 20 & Mi dò ghó bé & Mo jệ, ghò bẹ & I say you should look here \\
\hline 21 & Mu we nẹn kòmí & Múwé nẹn mi & Give me that book \\
\hline 22 & È see sọkọ ẹ? & Nẹn sọ́kọ́ ẹe? & Who is your husband? \\
\hline 23 & Aa mí yá & Arà mén yá & I am sick \\
\hline 24 & Ó dà ti la sùn ín? & O ti la hùn? & Has he gone to bed? \\
\hline 25 & Mẹní yẹn kò mí & Mẹ́ní yẹn mi & Give me that mat \\
\hline
\end{tabular}

\section{B. Data Analysis}

The analyses of the data are on two stages:

(i) Lexical Analysis

(ii) Syntactic Analysis

On lexical analysis, the main lexical items in the sentences of the two dialects are focused, equally, at the syntactic level; attention is paid to the main syntactic components of the sentences of the two dialects as follows;

\begin{tabular}{|c|c|c|c|c|c|c|c|c|c|c|c|}
\hline \multirow{2}{*}{$\begin{array}{l}\mathbf{S} / \\
\mathbf{N}\end{array}$} & \multicolumn{5}{|c|}{ Ondo } & \multicolumn{5}{|l|}{ Ikale } & \multirow{2}{*}{$\begin{array}{l}\text { Standard Yoruba } \\
\text { Form }\end{array}$} \\
\hline & $\mathrm{S}$ & Aux & $\mathrm{P}$ & $\mathrm{C}$ & $\mathrm{A}$ & $\mathrm{S}$ & Aux & $\mathrm{P}$ & $\mathrm{C}$ & $\mathrm{A}$ & \\
\hline 1 & - & we da ti & lọ in & - & & - & we ti & lọ & - & - & Se ẹ ti lọ. \\
\hline 2 & - & - & la ba & un & - & - & la ba & - & - & - & ẹ lọ ba. \\
\hline 3 & $\begin{array}{l}\text { iwe } \\
\text { nẹn }\end{array}$ & - & Saa & - & - & iwe nẹn & - & Hanan & - & - & Iwe naa da? \\
\hline 4 & - & - & wa jẹun & - & - & - & - & wa jẹun & - & - & ẹ wa jẹun. \\
\hline 5 & - & kii buwe & lọ & - & si & - & ki buwe & lọ & - & $\mathrm{Ni}$ & Nibo le n lọ. \\
\hline 6 & $\begin{array}{l}\text { ọkọ } \\
\text { nẹn }\end{array}$ & - & ti sáré & - & jù & ọkọ nẹn & - & ti háré & - & $\mathrm{Ju}$ & ọkọ re ti sare ju. \\
\hline 7 & $\mathrm{mi}$ & do mọ & gho nẹn & komi & & mo & jẹ & mogho & $\begin{array}{l}\text { nẹn } \\
\text { mi }\end{array}$ & - & $\begin{array}{l}\text { Mo in ki ẹ fun mi } \\
\text { lowo naa. }\end{array}$ \\
\hline 8 & - & We da ka & Sako & un & - & - & We ka & ha & un & - & ẹ sin ma sa fun. \\
\hline 9 & $\mathrm{Me}$ & la & Kàwé & - & - & me & la & kàwé & - & - & Mo fẹ lọ kawe. \\
\hline 10 & ma & - & Ii & ẹ & nola & ma & - & rii & ẹ & nọla & Ma ri ẹ lọla. \\
\hline 11 & $\mathrm{O}$ & - & dowurọ & - & & $\mathrm{O}$ & - & dowurọ & 0 & - & O daarọ o. \\
\hline 12 & - & - & Kaarọ & $\mathrm{o}$ & - & - & - & Kaarọ & o & - & Kaarọ o. \\
\hline 13 & - & Kẹn & ti i & - & $\mathrm{Ke} ?$ & - & $\mathrm{ki}$ & ngho ti gha & - & $\mathrm{Ke}$ & ba wo ni n kan? \\
\hline 14 & - & la & Joko & - & Si be in & - & la & joko & - & $\begin{array}{l}\text { hibe } \\
\text { yin }\end{array}$ & Lọ joko si bẹ yẹn. \\
\hline 15 & - & Kii gu we & bọ? & - & - & - & $\begin{array}{l}\text { Kii gbo } \\
\text { wo }\end{array}$ & bọ? & - & - & Igba wo lẹ de? \\
\hline 16 & Eelu & we & tọ o & - & - & kelu & we & ta & - & - & Elo lẹ n taa? \\
\hline 17 & - & laa & Sun & - & - & - & la ka & hun & - & - & ẹ lọ sun \\
\hline 18 & Emi & - & - & - & ee & emi & - & - & - & Ree & Emi ni yi. \\
\hline 19 & me & - & gbọ & ẹ & - & me & - & gbọ & ẹ & - & Mi o gbọ yin. \\
\hline 20 & - & - & do ji & $\mathrm{mi}$ & nowuọ & - & - & Jẹ ji & $\mathrm{Mi}$ & nowurọ & Ki ẹ ji mi laarọ \\
\hline 21 & $\mathrm{Mi}$ & - & do bọ & - & bé & Mo & - & Je bọ & - & - & Mo ni ki ẹ bọ si bi. \\
\hline 22 & - & - & $\mathrm{mu}$ & we & yen komí & - & - & $\mathrm{mu}$ & $\mathrm{We}$ & yẹn mi & ẹ mu iwe yẹn wa. \\
\hline 23 & aa & - & Meya & - & - & ara & - & mẹn ya & - & - & ara mi ko da. \\
\hline 24 & $\mathrm{O}$ & dati la & Sun & - & in & wo & ti la & hun & - & - & Se ẹ ti sun? \\
\hline 25 & - & - & Meni & yẹn & komi & - & - & meni & $\begin{array}{l}\text { yẹn } \\
\text { mi }\end{array}$ & - & ẹ fun mi lẹni yẹn. \\
\hline
\end{tabular}




$\begin{array}{lcl} & \text { Key } & \\ \text { S } & - & \text { Subject } \\ \text { P } & - & \text { Predicator } \\ \text { C } & - & \text { Complement } \\ \text { A } & - & \text { Adjunt } \\ \text { Aux } & - & \text { Auxilliary }\end{array}$

VOCABULARY TABLE 4

The Major Lexemes of the Dialects in the Analysed Sentences are as follows:

\begin{tabular}{|c|c|c|}
\hline $\mathbf{S} / \mathbf{N}$ & Ondo & Ikale \\
\hline 1. & Lọ (v) & Lọ (v) \\
\hline 2. & $\mathrm{Ba}(\mathrm{v})$ & $\mathrm{Ba}(\mathrm{v})$ \\
\hline 3. & İwé (noun) saa (adv) & İwé (noun) han an (adv) \\
\hline 4. & Jẹun (v) & Jẹun $(\mathrm{v})$ \\
\hline 5. & Ki bi (adv) lọ (v) sí(adv) & Kí bo (adv) họ (v) hí (adv) \\
\hline 6. & ọkọ (n) sá(v) & ọkọ $(\mathrm{n})$, bá $(\mathrm{v})$ \\
\hline 7. & Móghó (v) mi (pron) & Móghó (v) mi (pron) \\
\hline 8. & Sáàkó (v) & Háun (v) \\
\hline 9. & Kàwé (v) & Kàwé (v) \\
\hline 10. & Nọ́la (adv) & Nọla (adv) \\
\hline 11. & Owwúọ (adv) & Òwúọ (adv) \\
\hline 12. & Áárọ (adv) & Àárọ (adv) \\
\hline 13. & Ii (v) & Gba (v) \\
\hline 14. & Jòkó (v) & Jòkó (v) \\
\hline 15. & Wébọ (v) & Wobọ (v) \\
\hline 16. & Tọọ (v) & Taa (v) \\
\hline 17. & Sùn $(v)$ & Hùn (v) \\
\hline 18. & Ėmi (pron) & Ėmi (pron) \\
\hline 19. & $\mathrm{Ji}(\mathrm{v})$ & Jí (v) \\
\hline 20. & Ghò (v) & Ghò (v) \\
\hline 21. & Mí (pron) & Mi (pron) \\
\hline 22. & ọkọ (n) & okọ (n) \\
\hline 23. & $\mathrm{Aa}(\mathrm{n})$ & Ara (n) \\
\hline 24. & Sùn (v) & Hùn (v) \\
\hline 25. & ẹní (n) & ẹní (n) \\
\hline
\end{tabular}

$\begin{array}{lcl} & \text { Key } & \\ \text { N } & - & \text { noun } \\ \text { V } & - & \text { verb } \\ \text { Ad } & - & \text { adjective } \\ \text { Adv } & - & \text { adverb } \\ \text { Pron } & - & \text { pronoun } \\ \text { S } & - & \text { subject } \\ \text { P } & - & \text { Predicator } \\ \text { C } & - & \text { Complement } \\ \text { A } & - & \text { Adjunct }\end{array}$

C. Results of the Analysis for Both Ondo and Ikale Dialects.

1. The predicator - 'lọ' is the same for both dialects.

2. The lexeme at the predicator is the same 'ba'

3. The lexical items at the subject column is the same 'iwe', differs slightly at predicator level.

4. The words are similar in auxiliary and adjunct, but same in predicator $=$ jẹn

5. The same in main verb - predicator, but differs slightly in adjunct.

6. The words are similar in predicator but same in subject- okọ and adjunct 'ju'

7. The words in the Subject, Predicator and complement are the same.

8. Similar word is used at the predicator level.

9. Both subjects and predicators have the same lexemes.

10. The same lexemes in S, P, C and A.

11. Same lexemes are found in $\mathrm{S}, \mathrm{P}$ and $\mathrm{C}$

12. Same lexemes found in $P$ and $C$

13. The main lexical items are the same for $\mathrm{P}$ and $\mathrm{A}$

14. The word in $\mathrm{P}$ is the same in both dialects

15. The main lexemes in $P$ are the same in both dialects

16. The lexemes at $S$ and $P$ are slightly different but the auxiliaries are the same

17. The words are slightly different in P. 
18. The $\mathrm{S}$ lexemes are the same in both dialects

19. All the lexemes in $\mathrm{S}, \mathrm{P}$ and $\mathrm{C}$ are same

20. The main lexemes of $\mathrm{P}, \mathrm{C}$ and $\mathrm{A}$ are same for both dialects

21. Both the main lexemes of $\mathrm{P}$ and $\mathrm{A}$ are the same in the dialects

22. Items in $\mathrm{P}, \mathrm{C}$ and $\mathrm{A}$ are the same in both dialects

23. The items in $\mathrm{P}$ are the same in both dialects

The items in $\mathrm{S}$ are the same for both dialects

The items in P, C and A are same for both dialects

\section{FINDINGS FROM THE ANALYSIS}

From the analysis of the 25 sentences above; it is discovered that the two dialects have basically the same lexemes at subject and predicator positions (see the vocabulary table above), meaning that the speakers often use the same nominal and verbal items in most occasions. For example, out of the 25 sentences examined, 16 of the sentences have the same lexemes at the predicator level for both dialects; this represents $64 \%$ of the total lexemes at the predicator level.

In the same vein, at the subject level, (the nominal) out of 25 sentences examined, 16 of the sentences from both dialects have the same words or lexemes at the subject level, and this represents $64 \%$ again of the total words at this level. Granted that some of the sentences are imperative which do not require obvious subjects as found in sentences 1 , $2,4,5,8,12,15,17,20,22$ and 25. They are however, treated as having the same subjects, since they appear so, in both dialects. The obvious point here is that the two dialects often share the same lexemes at the subject level as shown in the data analyzed (see the vocabulary table). This also extends to Adjunct position, where some words/lexemes share the same forms in both dialects, as we have in sentences $6,10,21,22$, and 25 involving the words jù̀, nóla, nowùo, yen and yen respectively. Even some nominal items at the complement level, are also in the same form in both dialects, see sentences 7, 11, 20, 22 and 25. This further enhances the claim that the two dialects are very close in the area of lexical choice and usage.

Syntax

At the syntactic level, the two dialects share basically the same syntactic components subject, predicator, complement and adjunct (SPCA). Also, in both dialects, it is found that adjuncts are rarely used in the sentences. For instance, out of 25 sentences examined, only 8 have adjuncts attached. (See sentences 5, $610,13,14,20,21$, and 22) on the syntactic table, this represents $32 \%$ of the total sentences analysed. This low percentage thus confirms the claim that adjunct is seldom used in both dialects.

\section{THE IMPLICATIONS OF THE FINDINGS}

It is revealed from the analysis that the two dialects examined in this work are closely related in the areas of lexical selection and syntactic structures. They have virtually the same lexical items in both the subject and verbal (predicator) positions. Even in the adjunct position, a reasonable number of the lexemes are the same in both dialects. This implies that the dialects have almost the same lexicon or vocabulary. At the syntactic level, the two dialects have almost the same components at the syntactic level, as evident in the sentences below:

\begin{tabular}{|l|lll|lll|}
\hline Sentence Number & \multicolumn{2}{|l|}{ ONDO Dialect } & \multicolumn{1}{l|}{ IKALE Dialect } \\
\hline 2 & - & $\mathrm{P}$ & $\mathrm{C}$ & - & $\mathrm{P}$ & $\mathrm{C}$ \\
\hline 3 & - & $\mathrm{S}$ & $\mathrm{P}$ & - & $\mathrm{S}$ & $\mathrm{P}$ \\
\hline 4 & & - & $\mathrm{P}$ & & - & $\mathrm{P}$ \\
\hline 5 & - & $\mathrm{P}$ & $\mathrm{A}$ & - & $\mathrm{P}$ & $\mathrm{A}$ \\
\hline 6 & $\mathrm{~S}$ & $\mathrm{P}$ & $\mathrm{A}$ & $\mathrm{S}$ & $\mathrm{P}$ & $\mathrm{A}$ \\
\hline
\end{tabular}

Most of the sentences of the dialects are imperative: they are without subjects. However, there are still some major differences between the two dialects especially in the area of auxiliary verbs. The two dialects do not always make use of the same auxiliaries as shown in the sentences analyzed for this work. For example, in sentence 5, in Ondo dialect, the auxiliary is: bù and Ikale has bo; in sentence 15, Ondo has 'gu', while Ikale uses 'gbo' as while Ikale has jé, Ondo has do. In fact, these two auxiliaries (je and do) are the major markers of differences in the use of auxiliary verbs in the two dialects. This, however, does not mean, we do not have overlaps in the use of auxiliaries in the two dialects. The overlaps, for instance, are noticed in sentences 6, 8914,16 and so on, where both dialects have the same auxiliaries of $\underline{\mathrm{ti}}, \underline{\mathrm{ka}}, \underline{\mathrm{a}}, \underline{\mathrm{a}}$, wé respectively (see the syntactic table).

Orthographically, the two dialects are similar in several respects, as they share the same orthographic form for most of the words or lexemes. They are however, different in the use of the letters 's' and ' $\underline{s}$ ', while Ondo often uses letter 's $\underline{\text { ' }}$ for words that require it, Ikale uses letter ' $\underline{h}$ ' as we have in sentence 17 and 24 as in sùn and hùn, and sentence 6 has sáré for Ondo, and háré for Ikale. Then, it is also noticed that most of the words in these two dialects are similar to the words or vocabulary of the standard Yoruba, confirming this claim are words like lo (v) in sentence 1, ìwé (n) in sentence 3, jeun (v) in sentence 4, okọ (n) in sentence 6, àárọ (adv) in sentence 12 and so on. These words are also found in the standard Yoruba language. This explains reasons for mutual intelligibility of the two dialects to an average Yoruba speaker. In the area of syntax, the major difference between the two dialects and the standard Yoruba is that 
most of the sentences in the dialects are imperative, that is, without subject elements, while the standard Yoruba has always attracted subject elements (see the sentences in the standard Yoruba).phonologically, it should however, be emphasized that the two dialects in the table differ significantly from each other considering the way they are produced with respect to intonation, stress and so on. This area is not however, the focus of this paper, it will be taken up in the second version of this research later. As it is widely claimed that language is an element of culture, hence, Peccei (2004:9), views that "changes taking place in the socio-cultural, political and economic lives of human communities are not only expressed by language but are also promoted through the use of language" (Peccei, 2004, p. 14). So, language, which is part of culture, could be used not only to steer people's thoughts and beliefs but also to control those human and societal beliefs and thoughts. It is even argued by Salami (1993) that "language variety could become an ideology at a stage when a variety of a language is rated as low status as a result of the class of its speakers, since the social structuring of the variety is based on the relations of social and economic power" (Salami, 1993). In this respect, the two dialect examined in this paper, as a result of their relatedness as already proved, have endowed their speakers with similar cultural norms and practices such as eating similar foods, having similar mode of dressing, worshipping, festivals and so on.

\section{CONCLUSION}

The Ondo and Ikale dialects studied in this paper, share a lot of similarities and just few differences in the areas of Lexemes and Synthax. This is due, as discovered to the geographical proximity and cultural closeness of the two tribes.

It is envisaged that some of the dialects of Yoruba languages like the two examined in this paper, for reasons of proximity and historical factor, will equally share quite a lot of linguistic features. But quite a large number of them have vocabulary that are closely related to that of the standard Yoruba language as evident in Table I, hence the general mutual intelligibility of the dialects of Yoruba language to all the Yoruba speakers. This high degree of similarity of the two dialects has implication for traditions and norms (culture) in these dialectal communities, since language too, is an element of culture.

\section{REFERENCES}

[1] Aboderin, A. O. (2006). "Iyisodi ati Atupale ihun re ninu Eka-ede Awori". PhD. Thesis, Obafemi Awolowo University, Ile-Ife.

[2] Adetugbo, A. (1967). "The Yoruba Language in Western Nigeria: its major dialect areas". Unpublished Ph.D. Thesis, Columbia University.

[3] Adetugbo. (1973). "Yoruba Language in Yoruba History". In Biobaku, S: (ed.), Sources of Yoruba History. (pp. 176-204). Oxford: Clarendon Press.

[4] Adetugbo. (1982). 'Towards a Yoruba Dialectology.' In Afolayan A. (ed.) Yoruba Language and Literature. (pp. 207-224). Ife and Ibadan: University Press.

[5] Ajongbolo, P.O. (2005). "Negation in dialect of Yoruba". Unpublished Ph.D Thesis, University of Ibadan, Ibadan, Nigeria.

[6] Akere, F. (1977). A Sociolinguistic Study of a Yoruba Speech Community in Nigeria: variation and change in Ijebu dialect speech of Ikorodu. Unpublished Ph.D Thesis, University of Edingburgh, Edinburgh.

[7] Akmajian, A.et al. (2004). Linguistics: An Introduction to Language and Communication, India: Prentice-Hall of India.

[8] Awobuluyi, O. (1992). "Aspects of Contemporary Standard Yoruba in Dialectological Perspective”. In Isola A. (Ed.) New Findings in Yoruba Studies. Ibadan: Odunjo Memorial Lectures.

[9] Awoyale, Y. (1998). The Tense system of Yoruba: Linguistics and Nigerian Languages, Ilorin. pp. 1-26.

[10] Ellis, J. Ure. (1982). (eds.) "Register Range and Change", International Journal of Sociology of Language, Special Issue, vol. 35.

[11] Fabunmi, F. (1998). “Tense, Aspect and Modal Systems in Ijesa Dialect of Yoruba”. Unpublished M.A. Thesis, Department of Linguistics and African Languages, Obafemi Awolowo University, Ile-Ife, Nigeria.

[12] Fabunmi, F. (2001). "Notes on Ijesa Tense and Aspect Marking" in Studies in African Linguistics 30 pp. 113-114

[13] Fabunmi, F. (2003). "A GPSG Appraisal of Sequential Distributions of Auxiliary Verbs in Ijesa Dialect of Yoruba", Nordic Journal of African Studies, 12/3, pp. 355-371.

[14] Fabunmi, F. (2006). "Tense and Aspect in Mofoli Dialect of Yoruba", Unpublished Ph.D Thesis, Department of Linguistics and African Languages, Obafemi Awolowo University, Ile-Ife.

[15] Gregory, M. (1967). “Aspects of Varieties Differentiation”, in Journal of Linguistics, 3/2, 177-98.

[16] Halliday et al; (1964). The Linguistic Sciences and Language Teaching. London: Longmans Green and co ltd.

[17] Halliday, M.A.K. (1966). "Lexis as a Linguistic Level" in Bazzel (ed.) in, memory of J.R. Firth, J.R, London: Longman.

[18] Halliday, M.A.K. (1976). Halliday: System and Function in Language, Selected Papers. (ed. Gunther Kress). Oxford: Oxford University Press.

[19] Halliday, M.A.K. (1978). Language and Social Semiotic: The Social Interpretation of Meaning. London: Edward Arnold.

[20] Jones J. and Peccei. (2004). "Language and Politics" In Thomas L. Waveing, I Singh et al. (Eds.) Language, Society and Power, London and New York: Routledge.

[21] Jowitt, D. (2005). Nigerian English Usage: An Introductory, Lagos; Longman, Nigeria.

[22] Katzner, K. (1977). The Languages of the World, London and New York, Routledge and Kegan Paul pp. 10.

[23] Labov, W. (1963). "The social Motivation of a sound change". Word, 19:225-309

[24] Labov, William. (1972). Sociolinguistic Patterns. Philadelphia: University of Pennsylvania Press.

[25] Labov, William (1966). The Social Stratification of English in New York City. Washington, DC: Center for Applied Linguistics. 
[26] Mesthrie, R. et. al. (2003). Introducing Socio-Linguistics, Edinburgh: University Press Edinburgh.

[27] Milroy, L. (1987). "Language and Social Networks", Oxford: Blackwell.

[28] Salami L.O, (1993). "Language variation, Social diversity and social psychological explanations" in Nigerian Journal of Sociolinguistics, Vol. 2, No 3, Pp. 40-58.

[29] Salami L.O. (2006a). "Gender, Use and Attitude towards English Taboo Words among Young Adults in a Nigeria University", in The International Journal of Language, Culture and Society, Issue 17-2006.

[30] Salami L.O, (2010). "The Life and Times of Language" Unpublished Inaugural Lecture Series 229, Obafemi Awolowo University, Ile-Ife.

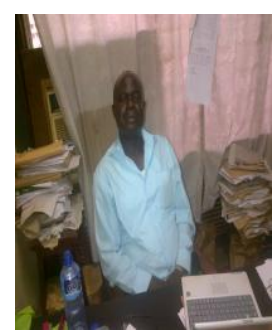

Omoniyi Moses Ayeomoni, is a senior Lecturer in the Department of English, Obafemi Awolowo University, Ile-Ife, Osun State Nigeria. He has published widely in both reputable local and International Journals and other publication outfits. He specializes in the fields of Applied Linguistics and Sociolinguistics.

He bagged all his degrees (B.A.(Hons.), M.A. and Ph.D) in the language area of English Studies. He also has a Postgraduate Diploma in Education (PGDE) from Obafemi Awolowo University, Ile Ife, Nigeria.

Dr. Ayeomoni studied in the three foremost Universities in Nigeria: (a) University of Ife (now OAU) for his Bachelor degree (1982-1986). (b) University of Lagos, Akoka, Lagos, for his Master degree (1989-1990). (c) University of Ibadan, Ibadan for his doctorate degree (2001-2007).

$\mathrm{He}$ is now teaching Linguistic Stylistics and Sociolinguistics in the Department of English, Obafemi Awolowo University, Ile-Ife, Nigeria. 